\title{
Debt Overhang, Costly Expandability and Reversibility, and Optimal Financial Structure
}

\author{
Jyh-Bang Jou and Tan LeE*
}

\begin{abstract}
This article compares the investment and financing decisions of a firm that adopts a 'first-best' strategy with those of a firm that adopts a 'secondbest' strategy. The former issues bonds upon deciding an initial capacity, while the latter issues bonds, and only then decides an initial capacity. The former is thus able to avoid the agency cost associated with the 'debt overhang' problem. Accordingly, the former will both issue more bonds and install a larger initial capacity than the latter. However, the agency cost of debt, i.e., firm value difference between these two strategies, is modest for plausible parameter values.
\end{abstract}

Keywords: bankruptcy costs, debt overhang, expandability, financial structure, reversibility

\section{INTRODUCTION}

The seminal article by Myers (1977) proposes two conjectures that have received wide attention in the finance literature.

* The authors are respectively from the Graduate Institute of National Development, College of Social Sciences, National Taiwan University; and the Department of International Business, College of Management, Yuan Ze University. They would like to thank Gunter Meissner, Walter Ness, Richard J. Briston, and especially an anonymous referee for their helpful comments and suggestions. Also, the authors would like to thank both the seminar participants in the First Finance Conference organized by the Portuguese Finance Network and the 2001 Global Finance Conference. The financial support under grant NSC-89-2416-H-002-068 from the National Science Council, Executive Yuan, R.O.C., is gratefully acknowledged. (Paper received September 2002, revised and accepted May 2003)

Address for correspondence: Tan Lee, 135 Yuan-Tung Rd., Department of International Business, College of Management, Yuan Ze University, Chung-Li, Taoyuan 320, Taiwan.

e-mail: tanlee@saturn.yzu.edu.tw 
Myers considers a firm that sequentially issues bonds, and then exercises an investment option. Given that the firm is acting in the interests of its equityholders after debt is in place, the firm will pass up projects with positive net present values because the firm's existing debt will capture most of the projects' benefits. Accordingly, the firm will under-invest as compared to a firm that issues no bonds. This 'debt overhang' problem is Myers' first conjecture. ${ }^{1}$ Myers asserts that the agency cost arising from the debt overhang problem is increasing with the firm's future growth opportunities. Given that both the firm and its creditors rationally anticipate equityholders' future behavior, Myers arrives at his second conjecture, namely, the firm with more future growth opportunities will take on less debt.

Myers does not formally validate his second conjecture even though he mentions that the firm he investigates will take on some debt if it also enjoys some benefits from issuing bonds (e.g. the tax shield benefits). In a recent article, Jou (2001b) reinvestigates Myers' two conjectures by assuming that a firm chooses its initial capacity ex post (that is, after debt is in place). Within Jou's framework, a firm in an environment where it is more costly to purchase capital later will have fewer future growth opportunities. Jou then shows that Myers' first conjecture always holds, and that Myers' second conjecture will also hold if certain conditions are satisfied. ${ }^{2}$

The firm investigated by Jou (2001b) adopts a 'second-best' investment option strategy (henceforth referred to as the second-best firm), and therefore, bears the agency cost associated with the debt overhang problem. Jou (2001b), however, does not consider the situation where a firm can either contract or otherwise credibly pre-commit its initial capacity and its debt level ex ante. In this situation, the firm adopts a 'first-best' investment option strategy (henceforth referred to as the firstbest firm) because the firm simultaneously chooses its initial capacity and its debt level to maximize total firm value. The

1 This conjecture can also be generalized to another conjecture that is widely tested in the empirical literature: leverage is inversely related to corporate value because a highly leveraged firm, which bears a higher agency cost of debt, will be less profitable (see, e.g., Callen and Gelb, 2000).

2 For example, if a lower cost of purchasing capital in the future mitigates the debt overhang problem. 
difference in maximal values between the first- and second-best firms can be used to measure the agency cost of debt because it reflects the loss in value that follows from the investment option strategy that maximizes equity value rather than firm value. This article will measure this agency cost of debt as well as compare the investment and financing decisions of the secondbest firm with those of the first-best firm. ${ }^{3}$

This article introduces debt financing into the model of Abel, Dixit, Eberly and Pindyck (1996), which examines the initial investment decision of an all-equity financed firm. In period 1, a firm adopts either the first- or second-best strategy. The firm then acts in the interests of equityholders after debt is in place regardless of the strategy it takes. Uncertainty arises at the beginning of period 2. In this period, the firm purchases capital at a price higher than that in period 1 so that it is costly for the firm to expand. In addition, the firm, in period 2, sells its installed capital at a price lower than the price it purchased in period 1 so that it is costly for the firm to reverse its action. After the state in period 2 is realized, the equityholders will either maintain, expand, or contract capacity and pay the debtholders off if this state of nature guarantees that levered equity value be non-negative; otherwise, the firm will go bankrupt. After bankruptcy, the debtholders will both control the firm and decide a level of capacity. Debt payments are tax deductible with full loss offsets, ${ }^{4}$ and some costs are associated with the event of bankruptcy. ${ }^{5}$

Given that both firms choose the same debt level, the first-best firm that is able to avoid the debt overhang problem will install a larger capacity in period 1 than the second-best firm. In addition, given that both firms choose the same capacity in period 1 , the first-best firm that is able to avoid the agency cost of debt will

3 In Leland (1998), a firm adopts the second-best investment option strategy if it bears agency costs associated with the asset substitution problem. By contrast, a firm adopts the first-best one if it is able to avoid such agency costs. In Mauer and Ott (2000), the first-best growth option exercise strategy is chosen to maximize total firm value, while the second-best one is chosen to maximize levered equity value. However, Mauer and Ott do not explicitly discuss whether the timing for issuing bonds is different for these two strategies.

4 Loss carry-forward or loss carry-backward will make losses exhibit partial offsets. We consider the polar case where losses exhibit a full offset here.

5 See related studies by Altman (1984), Haugen and Senbet (1978) and Warner (1977). 
issue more bonds than the second-best firm. We show that the first-best firm both issues more bonds and also installs a larger capacity in period 1 than the second-best firm when we allow interactions between investment and financing decisions. Given plausible parameter values, we also show that the agency cost of debt is modest (as a percentage of the second-best firm value).

This article is closely related to two articles by Brander and Lewis (1986 and 1988). ${ }^{6}$ Both of their articles use a sequential two-stage duopoly model to investigate the effects of financial structure on the product market and the resulting implications for financial decisions. The firm investigated in Brander and Lewis (1988) resembles the first-best firm considered in this article while the firm investigated in Brander and Lewis (1986) resembles the second-best firm considered in this article. Both of their articles, however, assume that firms operate at a fixed capacity, and therefore, do not allow capital investment to exhibit costly expandability or costly reversibility.

This article is also related to several articles that examine optimal capital structure in a dynamic continuous-time framework. Mello and Parsons (1992) measure the agency cost of debt investigated by Myers (1977), and compare the operating policy of a firm issuing bonds with that of a firm issuing no bonds. Mello, Parsons and Triantis (1995) show that a multinational firm can use forward contracts to hedge exchange rate exposure so as to reduce the agency costs generated by the debt overhang problem. Fries, Miller and Perraudin (1997) investigate the relationship between the elasticity of demand and optimal debt capacity in industry equilibrium in a model where debt financing leads to inefficient liquidation. Lambrecht (2001) investigates interactions between market entry, company closure, and capital structure in a duopoly. Mauer and Triantis (1994) analyze interactions between a firm's dynamic investment, operating, and financing decisions in a framework

6 Other related studies include Brander and Spencer (1989), Dasgupta and Sengupta (1993) and Mella-Barral and Perraudin (1997). The first study allows both moral hazard and limited liability, and relates a firm's optimal financial structure to output market structure. The second study allows bargaining between a firm and its workers to mitigate the debt overhang problem. The last study suggests that if equityholders are able to negotiate with debtholders prior to formal bankruptcy, then both direct bankruptcy costs and agency costs resulting from the debt overhang problem can be reduced. 
where the firm bears operating adjustment and recapitalization costs. Mauer and Ott (2000) investigate how the agency costs associated with the debt overhang problem affect a firm's financing and its growth option exercise decision. Finally, two studies by Jou (2001a and 2001c) investigate the optimal capital structure for the first-best firm. In Jou (2001a), a firm simultaneously issues bonds and pays a sunk cost to exercise a continuous-time fixed scale investment project. In Jou (2001c), a firm adds new bonds upon exercising the option to expand capacity. Both studies, however, do not discuss the case of the second-best firm, and therefore, do not measure the size of the agency cost of debt.

This article is organized as follows. In Section 2 we set up the basic model. In Section 3 we derive both a firm's capacity decision in period 2 and the solvent region in this same period. In Section 4 we characterize the period 1 capacity choice of the second-best firm in terms of $q$-theory, and then investigate how this choice is affected by a change in debt level. In Section 5 we derive the value of the debt in period 1. In Section 6 we first derive the financing decision of the second-best firm, and then compare this firm's choices of debt levels and period 1 capacity with their counterparts of the first-best firm. In Section 7 we examine how an increase in the bargaining cost associated with bankruptcy, and each of the purchase and resale prices of capital in period 2 affects the agency cost of debt, investment, financing, and bankruptcy decisions, as well as debt value and the debt-to-firm value ratio of these two firms. In the final section we present the concluding remarks.

\section{THE MODEL}

Abel, Dixit, Eberly and Pindyck (1996) build a two-period model in which a firm is free of taxation, is all-equity financed, and faces a rising cost of investment and a declining salvage value of installed capital in the later period. They interpret opportunities to the firm for investment or disinvestment as options on its assets and analyze how these options are related to the firm's initial capacity decision. We introduce both taxation and debt financing into this two-period setting, and allow 
a firm to take either the first- or second-best investment option strategy. Similar to that in Leland (1998), the first-best firm maximizes total firm value by issuing bonds upon exercising the investment option. This contrasts with Brander and Lewis (1988) in which a firm taking the first-best strategy maximizes total firm value by first issuing bonds, followed by producing final goods. In addition, in a way similar to the conventional literature on optimal capital structure (e.g., Jensen and Meckling, 1976; and Myers, 1977), the second-best firm is acting in the interests of equityholders after debt is in place. Given the future behavior of equityholders, the firm maximizes total firm value when choosing debt levels.

Jou (2001b) extends the model of Abel et al. (1996) to investigate the financing and investment decisions of the second-best firm. In this article we extend Jou's model to compare the investment and financing decisions of the first-best firm with those of the second-best firm. While Jou abstracts from bankruptcy costs, we allow bankruptcy costs for both the first- and second-best firms so as to ensure that both firms will issue a finite amount of bonds.

The basic model is as follows. In period 1, a firm issues bonds either upon or before the firm installs an initial capacity $K_{1}$ at unit cost $b$. The gross return to period 1 capital is denoted by $r\left(K_{1}\right)$ so that the net return to period 1 capital is equal to $r\left(K_{1}\right)-b K_{1}$. The marginal return to period 1 capital, $r_{K_{1}}\left(K_{1}\right)$, is both positive for finite values of $K_{1}$ and becomes lower as more period 1 capital is employed. The Inada conditions are satisfied, i.e., $\lim _{K_{1} \rightarrow 0} r_{K_{1}}\left(K_{1}\right)=\infty$, and $\lim _{K_{1} \rightarrow \infty}$ $r_{K_{1}}\left(K_{1}\right)=0$.

Uncertainty arises at the beginning of period 2. The uncertainty in period 2 is described by a disturbance term $e_{2}$ that affects the period 2 return to capital $R\left(K_{2}, e_{2}\right)(\geq 0)$, which is strictly increasing with $e_{2}$; the term $K_{2}$ is the firm's capacity in period 2 , and the term $e_{2}$ is distributed over the interval $(-\infty$, $+\infty)$ with a cumulative distribution $F\left(e_{2}\right)$. The marginal return to capital in period $2, R_{K_{2}}\left(K_{2}, e_{2}\right)$, has the following properties: first, $R_{K_{2}}\left(K_{2}, e_{2}\right)$ is positive for finite values of $K_{2}$. Second, $\partial R_{K_{2}}\left(K_{2}, e_{2}\right) / \partial e_{2}>0$ and $\partial R_{K_{2}}\left(K_{2}, e_{2}\right) / \partial K_{2}<0$, i.e., in period 2, a higher marginal return to capital is associated with either a better state or a lower capacity. Finally, the Inada conditions 
are satisfied, i.e., $\lim _{K_{2} \rightarrow 0} \quad r_{K_{2}}\left(K_{2}, e_{2}\right)=\infty$ and $\lim _{K_{2} \rightarrow \infty}$ $r_{K_{2}}\left(K_{2}, e_{2}\right)=0$.

Following Myers (1977), we assume that a firm is obliged to pay debtholders the par value of outstanding bonds, denoted by $B$, after the uncertainty in period 2 is resolved. We also assume that the equityholders control the firm after debt is in place. Accordingly, if the state of nature in period 2 is good enough, the equityholders will decide a new level of period 2 capacity, and they will then pay the debtholders off; otherwise, they will declare bankruptcy ${ }^{7}$ and then transfer assets to the debtholders. After bankruptcy, the debtholders will control the firm, reflecting the 'absolute priority' of debt claims. Two possibilities will then arise: (i) debtholders will cease to operate the firm, and they will receive a value equal to the salvage value of installed capital net of the cost associated with bankruptcy; and (ii) debtholders will continue to operate the firm by choosing a new level of capacity. The former possibility, which is adopted by Jou (2001a), corresponds to the worst outcome for debtholders. The latter, which corresponds to the best outcome for debtholders, resembles that of Brander and Lewis (1986), and will be adopted in what follows.

We assume that both $b_{h}$, the period 2 purchase price of capital, exceeds its period 1 price $b$, and $b_{l}$, the period 2 resale price of capital, is less than $b$. By denoting $U_{2}\left(K_{1}, K_{2}\right)$ as the firm's period 2 value before paying both taxes and debt obligations, then:

$$
U_{2}\left(K_{1}, K_{2}\right)=R\left(K_{2}, e_{2}\right)-1_{\left[K_{2}>K_{1}\right]} b_{h}\left(K_{2}-K_{1}\right)+1_{\left[K_{1}>K_{2}\right]} b_{l}\left(K_{1}-K_{2}\right),
$$

where $1_{[\cdot]}$ is an indicator function which is equal to one if the condition within [.] is satisfied, and zero otherwise. Equation (1) shows that $U_{2}\left(K_{1}, K_{2}\right)$ is equal to either (i) the period 2 pre-tax return to capital alone if $K_{2}=K_{1}$, (ii) the period 2 pre-tax return to capital minus the expansion costs if $K_{2}>K_{1}$, or (iii) the period 2 pre-tax return to capital plus the resale revenues if $K_{1}>K_{2}$.

Consider a firm that must both pay taxes and meet debt obligations. Denote $\tau(0<\tau<1)$ as the fixed corporate income

7 This resembles that in some recent articles on optimal capital structure (e.g., Leland, 1994 and 1998; and Mauer and Ott, 2000). 
tax rate applicable to the firm's taxable income in both periods 1 and 2. Furthermore, assume that debt obligations in period 2 are tax deductible, ${ }^{8}$ and losses in both periods 1 and 2 are fully offset. Levered equity value in period 1 is then given by:

$$
\pi_{1 E}\left(K_{1}\right)=(1-\tau)\left[r\left(K_{1}\right)-b K_{1}\right] .
$$

After the true state in period 2 is revealed, the firm will be obliged to pay the debtholders the par value of outstanding bonds $B$. In period 2, the equityholders have already received an amount equal to $\pi_{1 E}\left(K_{1}\right)$ given by (2), and they will not need to transfer this amount to the debtholders regardless of whether bankruptcy occurs. Accordingly, the limited liability of equity suggests that the relative magnitude between $U_{2}\left(K_{1}, K_{2}\right)$ given by (1) and $B$ determines whether the equityholders will declare bankruptcy in period 2. Two cases will then arise. First, $U_{2}$ $\left(K_{1}, K_{2}\right) \geq B$ so that the debtholders will be paid off. Accordingly, debt value in this period, $\pi_{2 D}\left(K_{1}, K_{2}\right)$, is equal to $B$, and levered equity value in period $2, \pi_{2 E}\left(K_{1}, K_{2}\right)$, is equal to $(1-\tau)\left[U_{2}\right.$ $\left.\left(K_{1}, K_{2}\right)-B\right]$. Second, $U_{2}\left(K_{1}, K_{2}\right)<B$ so that the firm is unable to pay the debtholders off. Accordingly, the firm will go bankrupt, and therefore, the debtholders will receive a value equal to $U_{2}$ $\left(K_{1}, K_{2}\right)$. However, the costs associated with bankruptcy must be deducted from this value. These costs can be divided into direct costs, such as legal fees and court fees, and indirect costs, such as the revenue loss if the firm is forbidden to operate. We will ignore this difference. Instead, we will follow Brander and Lewis (1988) who suggest that the costs borne by debtholders in the process of bargaining with equityholders should be related to the amount at stake. Consequently, we will assume that these bargaining costs are equal to a constant, $c(>0)$, multiplied by the shortfall of the net return to capital in period 2 from debt obligations, $B-U_{2}\left(K_{1}, K_{2}\right)$. As a result, debt value in period 2, $\pi_{2 D}\left(K_{1}, K_{2}\right)$, is equal to $U_{2}\left(K_{1}, K_{2}\right)-c\left[B-U_{2}\left(K_{1}, K_{2}\right)\right]$. In addition, due to the limited liability of equity, levered equity value in period $2, \pi_{2 E}\left(K_{1}, K_{2}\right)$, and the amount of taxation are both equal to zero. Pooling all of the above information yields:

8 As suggested by Myers (1977, Appendix), the tax authority may allow deductions on some maximum interest rate $\lambda(0<\lambda \leq 1)$ so that the maximum attainable tax shield is $\lambda \tau B$. In what follows, $\lambda=1$ is imposed for ease of exposition. 


$$
\begin{gathered}
\pi_{2 E}\left(K_{1}, K_{2}\right)=(1-\tau) \max \left[U_{2}\left(K_{1}, K_{2}\right)-B, 0\right], \\
\pi_{2 D}\left(K_{1}, K_{2}\right)=(1+c) \min \left[U_{2}\left(K_{1}, K_{2}\right), B\right]-c B .
\end{gathered}
$$

Now consider the situation in period 1 . Levered equity value in period 1, denoted by $V_{1 E}\left(K_{1}\right)$, consists of two parts: (i) the net return to period 1 capital given by $\pi_{1 E}\left(K_{1}\right)$ in (2); and (ii) the period 1 expected present value of equity in period 2 evaluated at the optimal level of period 2 capacity given by $\theta E_{1} V_{2 E}$ $\left(K_{1}\right)=\theta E_{1} \max _{K 2} \pi_{2 E}\left(K_{1}, K_{2}\right)$; the term $\theta$ is the (risk-adjusted) discount factor and the term $E_{1}$ is the operator of expectation taken at $t=1$. In other words, levered equity value in period 1 is given by:

$$
V_{1 E}\left(K_{1}\right)=\pi_{1 E}\left(K_{1}\right)+\theta E_{1} V_{2 E}\left(K_{1}\right) .
$$

Finally, by denoting $V_{1 D}\left(K_{1}\right)$ as debt value in period 1 , then:

$$
V_{1 D}\left(K_{1}\right)=\theta E_{1} V_{2 D}\left(K_{1}\right) .
$$

The term, $\theta E_{1} V_{2 D}\left(K_{1}\right)=\theta E_{1} \max _{K 2} \pi_{2 D}\left(K_{1}, K_{2}\right)$, is the period 1 expected present value of debt in period 2 evaluated at the optimal level of period 2 capacity, where $\pi_{2 D}\left(K_{1}, K_{2}\right)$ is given by $(3 \mathrm{~b})$.

\section{THE SOLVENT REGION IN PERIOD 2}

In this section, we will first derive the period 2 capacity decision of the firm considered by Abel et al. (1996) which is both free of taxation and all-equity financed, taking the firm's period 1 capacity as given. We will then do the same thing for a firm that must both pay taxes and meet debt obligations in period 2, taking both its choices of financial structure and period 1 capacity as given. After debt is in place, the equityholders are concerned only with the solvent region in period 2, i.e., the range of states over which the pre-tax net return to capital in period 2 more than offsets the par value of outstanding bonds. We will examine how this solvent region is affected by a change in period 1 capacity, the debt level, and both the purchase and resale prices of capital in period 2 . 
Consider the firm investigated by Abel et al. (1996). Define two critical values of $e_{2}, e_{2 h}$ and $e_{2 l}$, as:

$$
\left.R_{K_{2}}\left(K_{2}, e_{2 h}\right)\right|_{K_{2}=K_{1}}=b_{h} \quad \text { and }\left.\quad R_{K_{2}}\left(K_{2}, e_{2 l}\right)\right|_{K_{2}=K_{1}}=b_{l} .
$$

Assuming that the firm neither purchases nor sells capital during period $2, e_{2 h}$ is defined as the value of $e_{2}$ for which the marginal return to capital in period 2 is equal to the purchase price of capital in this same period. The term $e_{2 l}$ is defined as the value of $e_{2}$ for which the marginal return to capital in period 2 is equal to the resale price of capital in this same period. After $e_{2}$ is known, the capital stock will be adjusted to a new optimal level, which we denote by $K_{2}\left(e_{2}\right)$. The choice of period 2 capital stock is obtained by setting the derivative of $U_{2}\left(K_{1}, K_{2}\right)$ given by (1) with respect to $K_{2}$ equal to zero. The states of nature in period 2 can then be classified into three regions: $e_{2}>e_{2 n}$, $e_{2 l}>e_{2}$, and $e_{2 n} \geq e_{2} \geq e_{2 l}$. First, when $e_{2}>e_{2 h}$, it is optimal to purchase capital until the marginal return to capital in period 2 equals the purchase price of capital in this same period, so $K_{2}\left(e_{2}\right)$ is given by $R_{K_{2}}\left(K_{2}\left(e_{2}\right), e_{2}\right)=b_{h}$. Second, when $e_{2 l}>e_{2}$, it is optimal to sell capital until the marginal return to capital in period 2 equals the resale price of capital in this same period, so $K_{2}\left(e_{2}\right)$ is given by $R_{K_{2}}\left(K_{2}\left(e_{2}\right), e_{2}\right)=b_{l}$. Finally, when $e_{2 h} \geq e_{2} \geq e_{2 l}$, it is optimal to neither purchase nor sell capital, so $K_{2}\left(e_{2}\right)=K_{1}$. It is obvious that the marginal return to capital in period 2 will lie between a floor, $b_{l}$, and a ceiling, $b_{h}$.

Consider a firm that both faces taxation and acts in the interests of its equityholders after debt is in place. Accordingly, the firm will choose a level of capacity in period 2 to maximize levered equity value in the same period, $\pi_{2 E}\left(K_{1}, K_{2}\right)$ as given by (3a). Setting the derivative of this equity value with respect to $K_{2}$ equal to zero yields the firm's choice of capacity in period 2, which resembles that investigated by Abel et al. (1996) when the realized state has a value of $e_{2}$ larger than a cutoff value.

Incorporating the firm's capacity choice in period 2 yields this cutoff value. Suppose that $\hat{e}_{2}$ denotes the break-even value of $e_{2}$ assuming that the firm does not purchase nor sell capital in period 2, i.e.: 


$$
R\left(K_{1}, \hat{e}_{2}\right)-B=0,
$$

where $R\left(K_{1}, \hat{e}_{2}\right)$ denotes the value of $R\left(K_{2}, \ell_{2}\right)$ evaluated at $K_{2}=K_{1}$ and $e_{2}=\hat{e}_{2}$. Three cases will then arise: $e_{2 h} \geq \hat{e}_{2} \geq e_{2 l}$, $\hat{e}_{2}>e_{2 h}$, and $e_{2 l}>\hat{e}_{2}$. First, if $e_{2 h} \geq \hat{e}_{2} \geq e_{2 l}$, then the premise is verified so that $\hat{e}_{2}$ will be also the cutoff value of $e_{2}$ relevant to the firm's equityholders. We will call this cutoff value $\hat{e}_{2 m}$. Accordingly, the solvent region in period 2 is given by $e_{2}>\hat{e}_{2 m}$. Second, if $\hat{e}_{2}>e_{2 h}$, the equityholders will be better off if they expand rather than maintain capacity at $e_{2}=\hat{e}_{2}$. As a result, the solvent region in period 2 should extend to the left of $\hat{e}_{2}$, and the associated cutoff value, denoted by $\hat{e}_{2 h}$, satisfies the equation given by:

$$
R\left(K_{2}\left(\hat{e}_{2 h}\right), \hat{e}_{2 h}\right)-b_{h}\left(K_{2}\left(\hat{e}_{2 h}\right)-K_{1}\right)-B=0 .
$$

The solvent region in period 2 is given by $e_{2}>\hat{e}_{2 h}$. Finally, if $e_{2 l}>\hat{e}_{2}$, the equityholders will be better off if they contract rather than maintain capacity at $e_{2}=\hat{e}_{2}$. As a result, the solvent region in period 2 should extend to the left of $\hat{e}_{2}$, and the associated cutoff value, denoted by $\hat{e}_{2 l}$, satisfies the equation given by:

$$
R\left(K_{2}\left(\hat{e}_{2 l}\right), \hat{e}_{2 l}\right)+b_{l}\left(K_{1}-K_{2}\left(\hat{e}_{2 l}\right)\right)-B=0 .
$$

Accordingly, the solvent region in period 2 is given by $e_{2}>\hat{e}_{2 l}$. Figure 1 presents the relationship among $e_{2 h}, e_{2 l}, \hat{e}_{2}, \hat{e}_{2 m}, \hat{e}_{2 h}$, and $\hat{e}_{2 l}$. Proposition 1 follows from $(6 \mathrm{a})-(6 \mathrm{c})$.

Proposition 1: The firm is more likely to fall into bankruptcy in period 2 if (i) the firm installs a smaller capacity in period 1, (ii) the firm takes on more debt, (iii) the firm purchases capital at a

\section{Figure 1}

The Relationship Among $e_{2 h}, e_{2 l}, \hat{e}_{2}, \hat{e}_{2 m}, \hat{e}_{2 h}$ and $\hat{e}_{2 l}$

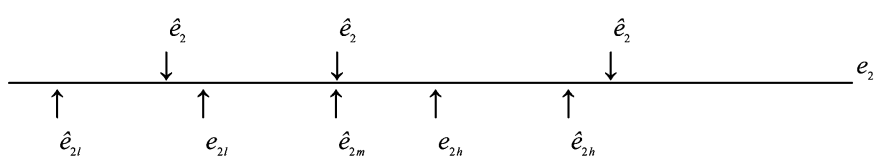


higher price at the state where it is on the verge of bankruptcy in period 2, and (iv) the firm sells installed capital at a lower price at the state where it is on the verge of bankruptcy in period 2.

Proof: See Appendix A.

\section{THE SECOND-BEST FIRM'S PERIOD 1 CAPACITY DECISION}

In this section, we will first calculate the period 1 expected present value of equity in period 2. This calculated value, plus the net return to capital in period 1 given by (2), yields levered equity value in period $1, V_{1 E}\left(K_{1}\right)$, given by (4a). Second, we will derive the choice of period 1 capacity of the second-best firm in accordance with $q$-theory (Tobin, 1969), taking its financial structure as predetermined. Finally, we will examine how a change in leverage affects this choice.

We begin by deriving the period 1 expected value of equity in period 2, which is the second term without the multiplier $\theta$ in (4a), i.e., $E_{1} V_{2 E}\left(K_{1}\right)=E_{1} \max _{K_{2}} \pi_{2 E}\left(K_{1}, K_{2}\right)$. Substituting (3a) into this expression yields $E_{1} V_{2 E}\left(K_{1}\right)$ as given by $(1-\tau) E_{1} \max _{K_{2}}$ $\left[U_{2}\left(K_{1}, K_{2}\right)-B, 0\right]$. Let $Z\left(K_{1}, e_{2}\right)$ denote $U_{2}\left(K_{1}, K_{2}\right)$ given by $(1)$ at the state where the firm decides to expand capacity in period 2 $\left(K_{2}>K_{1}\right)$. Let $Y\left(K_{1}, e_{2}\right)$ denote $U_{2}\left(K_{1}, K_{2}\right)$ at the state where the firm decides to contract capacity in period $2\left(K_{1}>K_{2}\right)$. In other words:

$$
\begin{aligned}
& \left.Z\left(K_{1}, e_{2}\right)=R\left(K_{2}\left(e_{2}\right), e_{2}\right)-b_{h}\left(K_{2}\left(e_{2}\right)-K_{1}\right)\right), \\
& Y\left(K_{1}, e_{2}\right)=R\left(K_{2}\left(e_{2}\right), e_{2}\right)+b_{l}\left(K_{1}-K_{2}\left(e_{2}\right)\right) .
\end{aligned}
$$

Combining the rule for the choice of capacity in period 2 derived in Section 3 with (7) yields:

$$
\begin{gathered}
E_{1} V_{2 E}\left(K_{1}\right)=(1-\tau)\left[\int_{\hat{e}_{2 m}}^{e_{2 h}}\left(R\left(K_{1}, e_{2}\right)-B\right)+\int_{e_{2 h}}^{\infty}\left(Z\left(K_{1}, e_{2}\right)-B\right)\right] d F\left(e_{2}\right),(8 \mathrm{a}) \\
E_{1} V_{2 E}\left(K_{1}\right)=(1-\tau) \int_{\hat{e}_{2 h}}^{\infty}\left(Z\left(K_{1}, e_{2}\right)-B\right) d F\left(e_{2}\right),
\end{gathered}
$$




$$
\begin{aligned}
E_{1} V_{2 E}\left(K_{1}\right)= & (1-\tau)\left[\int_{\hat{e}_{2 l}}^{e_{2 l}}\left(Y\left(K_{1}, e_{2}\right)-B\right) d F\left(e_{2}\right)+\int_{e_{2 l}}^{e_{2 h}}\left(R\left(K_{1}, e_{2}\right)-B\right) d F\left(e_{2}\right)\right. \\
& \left.+\int_{e_{2 h}}^{\infty}\left(Z\left(K_{1}, e_{2}\right)-B\right) d F\left(e_{2}\right)\right]
\end{aligned}
$$

should the equityholders decide to either maintain capacity (8a), expand capacity (8b), or contract capacity (8c), respectively, at the state where the firm is on the verge of bankruptcy in period 2.

Given that the equityholders control the firm after debt is in place, the equityholders will choose a level of capacity to maximize levered equity value in period $1, V_{1 E}\left(K_{1}\right)$ in (4a). Assuming that an interior solution exists, the choice of period 1 capacity is obtained by setting $V_{1 E}\left(K_{1}\right)$ with respect to $K_{1}$ equal to zero, i.e.,

$$
\frac{\partial V_{1 E}\left(K_{1}\right)}{\partial K_{1}}=0 .
$$

Substituting both $\pi_{1 E}\left(K_{1}\right)$ given by (2) and $E_{1} V_{2 E}\left(K_{1}\right)$ given by (8a)-(8c) into the right-hand side of (4a), and then partially differentiating the result with respect to $K_{1}$ yields the explicit form of (9) as given by:

$$
\begin{aligned}
&(1-\tau) r_{K_{1}}\left(K_{1}\right)+(1-\tau) \theta\left\{\int_{\hat{e}_{2 n}}^{e_{2 h}} R_{K_{2}}\left(K_{1}, e_{2}\right) d F\left(e_{2}\right)+b_{h}\left[1-F\left(e_{2 h}\right)\right]\right\} \\
&=(1-\tau) b \\
&(1-\tau) r_{K_{1}}\left(K_{1}\right)+(1-\tau) \theta b_{h}\left[1-F\left(\hat{e}_{2 h}\right)\right]=(1-\tau) b, \\
&(1-\tau) r_{K_{1}}\left(K_{1}\right)+(1-\tau) \theta\left\{b_{l}\left[F\left(e_{2 l}\right)-F\left(\hat{e}_{2 l}\right)\right] .\right. \\
&\left.+\int_{e_{2 l}}^{e_{2 h}} R_{K_{2}}\left(K_{1}, e_{2}\right) d F\left(e_{2}\right)+b_{h}\left[1-F\left(e_{2 h}\right)\right]\right\}=(1-\tau) b,
\end{aligned}
$$

should the equityholders decide to maintain capacity (10a), expand capacity (10b), or contract capacity (10c), respectively, at the state where the firm is on the verge of bankruptcy in 
period 2. Among the three possible levels of capacity in period 1 that satisfy equations $(10 \mathrm{a})-(10 \mathrm{c})$, the equityholders will choose the one that yields the highest equity value in period 1 . Conditions $(10 \mathrm{a})-(10 \mathrm{~b})$ are expressed in accordance with $q$-theory where the terms on the right-hand side represent the marginal value of period 1 capital, while the terms on the left-hand side represent the marginal cost of period 1 capital. Proposition 2 follows from condition (9).

Proposition 2: (The Debt Overhang Problem) The second-best firm will install a smaller capacity in period 1 as it issues more bonds.

Proof: See Jou (2001b).

The result in Proposition 2 resembles the debt overhang problem pointed out by Myers (1977). As is shown later in Section 6, the second-best firm bears an agency cost associated with this problem. The financing and investment decisions of this firm thus differ from those of the first-best firm that is able to avoid the agency cost.

\section{DEBT VALUE IN PERIOD 1}

If potential debtholders are foresighted, then the firm can only sell the bonds at their true value. This true value is the period 1 expected present value of debt in period 2, i.e., $V_{1 D}\left(K_{1}\right)=$ $\theta E_{1} V_{2 D}\left(K_{1}\right)=\theta E_{1} \max _{K_{2}} \pi_{2 D}\left(K_{1}, K_{2}\right)$, where $\pi_{2 D}\left(K_{1}, K_{2}\right)$ is given by (3b). To calculate $E_{1} V_{2 D}\left(K_{1}\right)$, we face a problem of maximizing debt value in period 2 , as if debtholders were running the firm in this same period. Setting the derivative of debt value in period $2, \pi_{2 D}\left(K_{1}, K_{2}\right)$ with respect to $K_{2}$, equal to zero yields the debtholders' choice of capacity in period 2, which resembles that investigated by Abel et al. (1996) provided that the state of nature $e_{2}$ is smaller than the cut-off value of $e_{2}$, i.e., $\hat{e}_{2 i}$ $(i=m, h, l)$ defined in Section 3 .

The period 1 expected value of debt in period $2, E_{1} V_{2 D}\left(K_{1}\right)$, includes three portions: (i) the expected value when the firm is insolvent, i.e., the integral of the optimized value of $U_{2}\left(K_{1}, K_{2}\right)$ over the insolvent region; (ii) the expected value when the firm 
is solvent, i.e., $B$ multiplied by $1-F\left(\hat{e}_{2 i}\right)(i=m, h$, or $l)$; and (iii) the expected bargaining cost associated with bankruptcy, i.e., the term $-c$ multiplied by the integral of the optimized value of $B-U\left(K_{1}, K_{2}\right)$ over the insolvent region. Summing these three terms and then multiplying the result by $\theta$ yields $V_{1 D}\left(K_{1}\right)=\theta E_{1} V_{2 D}\left(K_{1}\right)$ as given by:

$$
\begin{aligned}
V_{1 D}\left(K_{1}\right)= & \theta(1+c)\left[\int_{-\infty}^{e_{2 l}} Y\left(K_{1}, e_{2}\right) d F\left(e_{2}\right)+\int_{e_{2 l}}^{\hat{e}_{2 m}} R\left(K_{1}, e_{2}\right) d F\left(e_{2}\right)\right] \\
& +\theta\left[1-(1+c) F\left(\hat{e}_{2 m}\right)\right] B, \\
V_{1 D}\left(K_{1}\right)= & \theta(1+c)\left[\int_{-\infty}^{e_{2 l}} Y\left(K_{1}, e_{2}\right) d F\left(e_{2}\right)+\int_{e_{2 l}}^{e_{2 h}} R\left(K_{1}, e_{2}\right) d F\left(e_{2}\right)\right. \\
& \left.+\int_{e_{2 h}}^{\hat{e}_{2 h}} Z\left(K_{1}, e_{2}\right) d F\left(e_{2}\right)\right]+\theta\left[1-(1+c) F\left(\hat{e}_{2 h}\right)\right] B, \\
V_{1 D}\left(K_{1}\right)= & \theta(1+c) \int_{-\infty}^{\hat{e}_{2 l}} Y\left(K_{1}, e_{2}\right) d F\left(e_{2}\right)+\theta\left[1-(1+c) F\left(\hat{e}_{2 l}\right)\right] B,
\end{aligned}
$$

should the debtholders decide to maintain capacity (11a), expand capacity (11b), or contract capacity (11c), respectively, at the state where the firm is on the verge of bankruptcy in period 2.

Partially differentiating $V_{1 D}\left(K_{1}\right)$ given by (11a)-(11c) with respect to $K_{1}$ yields:

$$
\begin{gathered}
\frac{\partial V_{1 D}\left(K_{1}\right)}{\partial K_{1}}=\theta(1+c)\left[b_{l} F\left(e_{2 l}\right)+\int_{e_{2 l}}^{\hat{e}_{2 m}} R_{K_{2}}\left(K_{1}, e_{2}\right) d F\left(e_{2}\right)\right]>0, \\
\frac{\partial V_{1 D}\left(K_{1}\right)}{\partial K_{1}}=\theta(1+c)\left[b_{l} F\left(e_{2 l}\right)+\int_{e_{2 l}}^{e_{2 h}} R_{K_{2}}\left(K_{1}, e_{2}\right) d F\left(e_{2}\right)+b_{h}\left(F\left(\hat{e}_{2 h}\right)-F\left(e_{2 h}\right)\right)\right] \\
>0
\end{gathered}
$$

A firm that installs a larger capacity in period 1 will have a higher pre-tax net return to capital in period 2, $U_{2}\left(K_{1}, K_{2}\right)$, 
given by (1). Consequently, the firm's debt value in period 2, $\pi_{2 D}\left(K_{1}, K_{2}\right)$, given by $(3 \mathrm{~b})$, will be higher in the states where the firm is insolvent in this same period, but will be unchanged otherwise. Based on (12a)-(12c), the firm's debt value in period 1 , which is the period 1 expected present value of debt in period 2, will thus be higher.

\section{THE SECOND-BEST STRATEGY VS. THE FIRST-BEST STRATEGY}

In Section 4 we examined the second-best firm's choice of period 1 capacity, taking the firm's financial structure as given. In this section we discuss the determinants of this firm's financial structure, and then compare the results with those of the first-best firm. ${ }^{9}$

The effect of debt financing on the second-best firm's choice of period 1 capacity, denoted by $K_{1 s}$, will be rationally anticipated by the firm and its creditors. Consequently, the secondbest firm will maximize the value of the firm upon issuing bonds, given this period 1 capacity decision. The second-best firm's value in period $1, V_{1}\left(K_{1 s}\right)$, is the sum of its equity value in period $1, V_{1 E}\left(K_{1 s}\right)$ given by $(4 \mathrm{a})$, and its debt value in period 1 , $V_{1 D}\left(K_{1 s}\right)$ given by $(4 \mathrm{~b})$. In other words:

$$
V_{1}\left(K_{1 s}\right)=V_{1 E}\left(K_{1 s}\right)+V_{1 D}\left(K_{1 s}\right) .
$$

The marginal effect of an increase in debt on the value of the second-best firm in period 1 is given by the derivative of $V_{1}\left(K_{1 s}\right)$ in (13) with respect to $B$, i.e.:

$$
\frac{d V_{1}\left(K_{1 s}\right)}{d B}=\left(\frac{\partial V_{1 E}\left(K_{1 s}\right)}{\partial K_{1}}\right) \frac{d K_{1 s}}{d B}+\left(\frac{\partial V_{1 D}\left(K_{1 s}\right)}{\partial K_{1}}\right) \frac{d K_{1 s}}{d B}+\frac{\partial V_{1}\left(K_{1 s}\right)}{\partial B} .
$$

The three terms on the right-hand side of (14) may be interpreted as follows. The first term represents the effect of higher leverage on the second-best firm's equity value in period 1 through its induced effect on the choice of period 1 capacity. This effect vanishes by means of (9). The second term represents the effect of higher leverage on the second-best

9 We abstract from several considerations of debt financing, such as that bonds may either convey private information to capital markets, mitigate adverse selection effects, or affect the outcome of corporate control contests (see, e.g., Harris and Raviv, 1991). 
firm's debt value in period 1 through its induced effect on the choice of period 1 capacity. This effect, which is negative based on Proposition 2 and equations (12a)-(12c), indicates that higher leverage exacerbates the conflict of interest between equity and debt holders, and therefore lowers the second-best firm's debt value in period 1 . This second term thus resembles the kind of agency cost investigated by Myers (1977). The final term can be expressed as:

$$
\left[\tau \theta\left(1-F\left(\hat{e}_{2 i}\right)\right)\right]-c \theta F\left(\hat{e}_{2 i}\right),
$$

where the subscript $i$ is equal to $m, h$, or $l$ if the equityholders respectively decide to either maintain, expand, or contract capacity at the state where the firm is on the verge of bankruptcy in period 2. This final term is equal to the expected present value of the net return to capital in period 2 shielded from taxation per unit increase of bonds, net of the expected present value of the cost associated with bankruptcy in period 2 per unit increase of bonds. The second-best firm's choice of debt level is derived by setting $d V_{1}\left(K_{1 s}\right) / d B$ in (14) equal to zero, i.e.:

$$
\frac{\partial V_{1 D}\left(K_{1 s}\right)}{\partial K_{1}} \frac{d K_{1 s}}{d B_{s}}+\frac{\partial V_{1}\left(K_{1 s}\right)}{\partial B}=0 .
$$

Condition (16) indicates that the second-best firm chooses its debt level by equating the marginal tax shield benefit to the sum of the marginal agency cost asserted by Myers and the marginal bankruptcy cost. As mentioned before, the second-best firm first decides its debt level, and only then decides its initial capacity. The former decision is characterized by condition (16), while the latter is characterized by condition (9). These two conditions jointly determine two endogenous variables: the second-best firm's choice of capacity in period $1, K_{1 s}(\cdot)$, and its choice of debt level, denoted by $B_{s}(\cdot)$, where the symbol ' ' denotes the underlying exogenous variables. The second-best firm's equity value in period 1 given by (4a) and its debt value given by (4b) can thus be expressed as $V_{1 E}\left(K_{1 s}(\cdot), B_{s}(\cdot), \cdot\right)$ and $V_{1 D}\left(K_{1 s}(\cdot)\right.$, $\left.B_{S}(\cdot), \cdot\right)$, respectively. Condition (9) can thus be rewritten as:

$$
\frac{\partial V_{1 E}\left(K_{1 s}(\cdot), B_{s}(\cdot), \cdot\right)}{\partial K_{1}}=0 .
$$


Equation $\left(9^{\prime}\right)$ implicitly defines the dependence of $K_{1 s}$ on $B_{s}$. Totally differentiating $\left(9^{\prime}\right)$ with respect to $B_{s}$, and then rearranging yields:

$$
\frac{d K_{1 s}}{d B_{s}}=\frac{\Delta_{12}}{-\Delta_{11}}<0
$$

where:

$$
\begin{gathered}
\Delta_{11}=\frac{\partial^{2} V_{1 E}\left(K_{1 s}(\cdot), B_{s}(\cdot), \cdot\right)}{\partial K_{1}^{2}}<0,{ }^{10} \\
\Delta_{12}=\frac{\partial^{2} V_{1 E}\left(K_{1 s}(\cdot), B_{s}(\cdot), \cdot\right)}{\partial K_{1} \partial B}<0 .
\end{gathered}
$$

The negative sign given by (17a), which restates the debt overhang problem (see Proposition 2), is depicted by the line $X^{s} X^{s}$ in Figure 2.

\section{Figure 2}

The First-Best vs. the Second-Best Firm

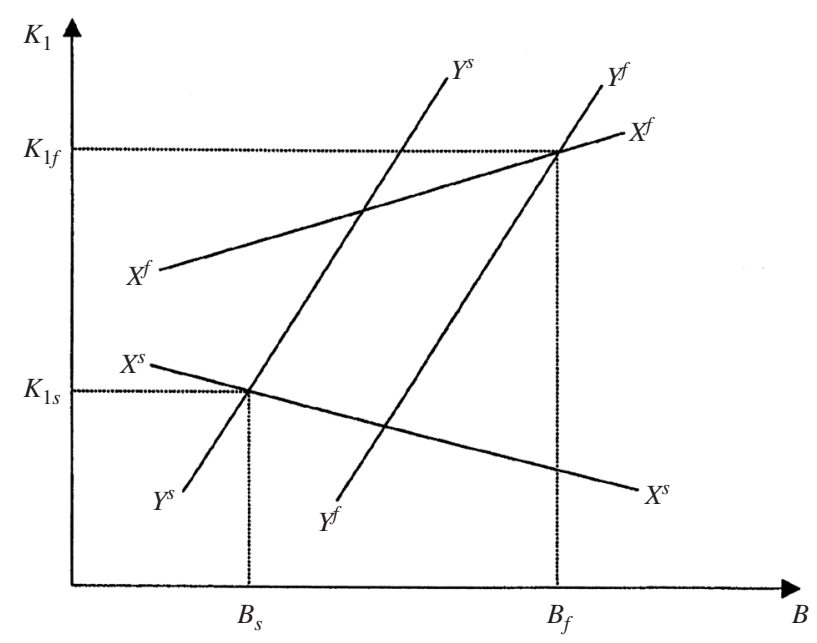

10 This is the second-order condition for $K_{1 s}$ to be an interior solution. We will assume it holds in what follows. 
Similarly, condition (16) can be written as:

$$
\frac{\partial V_{1 D}\left(K_{1 s}(\cdot), B_{s}(\cdot), \cdot\right)}{\partial K_{1}} \frac{d K_{1 s}}{d B_{s}}+\frac{\partial V_{1}\left(K_{1 s}(\cdot), B_{s}(\cdot), \cdot\right)}{\partial B}=0 .
$$

Condition $\left(16^{\prime}\right)$ implicitly defines the dependence of $B_{s}$ on $K_{1 s}$. Totally differentiating $\left(16^{\prime}\right)$ with respect to $K_{1 s}$ yields:

$$
\frac{d B_{s}}{d K_{1 s}}=\frac{\Delta_{21}}{-\Delta_{22}}>0
$$

$$
\begin{aligned}
& \text { where } \Delta_{21}=\frac{\partial^{2} V_{1 D}\left(K_{1 s}(\cdot), B_{s}(\cdot), \cdot\right)}{\partial K_{1}^{2}} \frac{d K_{1 s}}{d B_{s}}+\frac{\partial^{2} V_{1}\left(K_{1 s}(\cdot), B_{s}(\cdot), \cdot\right)}{\partial B \partial K_{1}}>0 \text {, } \\
& (-) \quad(-) \quad(+) \\
& \Delta_{22}=\frac{\partial^{2} V_{1 D}\left(K_{1 s}(\cdot), B_{s}(\cdot), \cdot\right)}{\partial K_{1} \partial B} \frac{d K_{1 s}}{d B_{s}}+\frac{\partial V_{1 D}\left(K_{1 s}(\cdot), B_{s}(\cdot), \cdot\right) d^{2} K_{1 s}}{\partial K_{1}}+\frac{\partial^{2} V_{1}\left(K_{1 s}(\cdot), B_{s}(\cdot), \cdot\right)}{\partial B^{2}}<0 .{ }^{11} \\
& (+) \quad(-) \quad(+) \quad\left(\frac{>}{<} 0\right) \quad(-)
\end{aligned}
$$

The positive sign of $(18 \mathrm{a})^{12}$ is depicted by the line $Y^{\rtimes} Y^{\rtimes}$ in Figure 2, which indicates that the second-best firm issues more bonds when installing a larger capacity in period 1 .

The solution for the second-best firm can be compared with that for the first-best firm which simultaneously issues bonds and installs capacity in period 1 . Suppose that the choice of $K_{1}$ is denoted by $K_{1 f}(\cdot)$ and that in relation to $B$ is denoted by $B_{f}(\cdot)$ for the first-best firm. Accordingly, $K_{1 f}(\cdot)$ and $B_{f}(\cdot)$ are derived by partially differentiating the value of the first-best firm in period 1 with respect to both $K_{1}$ and $B$, and then setting these derivatives equal to zero, respectively, i.e.,

$$
\frac{\partial V_{1}\left(K_{1 f}(\cdot), B_{f}(\cdot), \cdot\right)}{\partial K_{1}}=\frac{\partial V_{1 E}\left(K_{1 f}(\cdot), B_{f}(\cdot), \cdot\right)}{\partial K_{1}}+\frac{\partial V_{1 D}\left(K_{1 f}(\cdot), B_{f}(\cdot), \cdot\right)}{\partial K_{1}}=0,
$$

11 For both $K_{1 s}(\cdot)$ and $B_{s}(\cdot)$ to be interior solutions, it is required that $\Delta_{22}<0$. We will assume that this holds in what follows, e.g., if $d^{2} K_{1 s} / d B_{s}^{2} \leq 0$, then this condition will hold.

12 Equations (17a) and (18a) have opposite signs because they come from different first-order conditions that have different objective functions. The former comes from $\left(9^{\prime}\right)$ in which equity value is maximized. The latter comes from (16) in which total firm value is maximized. 


$$
\frac{\partial V_{1}\left(K_{1 f}(\cdot), B_{f}(\cdot), \cdot\right)}{\partial B}=0 .
$$

Condition (19) implicitly defines the dependence of $K_{1 f}$ on $B_{f}$. Totally differentiating (19) with respect to $B_{f}$, and then rearranging yields:

$$
\frac{d K_{1 f}}{d B_{f}}=\frac{\Delta_{12}^{\prime}}{-\Delta_{11}^{\prime}}>0
$$

where:

$$
\begin{gathered}
\Delta_{11}^{\prime}=\frac{\partial^{2} V_{1}\left(K_{1 f}(\cdot), B_{f}(\cdot), \cdot\right)}{\partial K_{1}^{2}}<0,{ }^{13} \\
\Delta_{12}^{\prime}=\frac{\partial^{2} V_{1}\left(K_{1 f}(\cdot), B_{f}(\cdot), \cdot\right)}{\partial K_{1} \partial B}>0 .
\end{gathered}
$$

The positive sign given by (21a) is depicted by the line $X^{f} X^{f}$ in Figure 2, which indicates that the first-best firm installs a larger capacity in period 1 when issuing more bonds.

Condition (20) implicitly defines the dependence of $B_{f}$ upon $K_{1 f}$. Totally differentiating it with respect to $K_{1 f}$, and then rearranging yields:

$$
\frac{d B_{f}}{d K_{1 f}}=\frac{\Delta_{21}^{\prime}}{-\Delta_{22}^{\prime}}>0
$$

where:

$$
\begin{aligned}
& \Delta_{21}^{\prime}=\frac{\partial^{2} V_{1}\left(K_{1 f}(\cdot), B_{f}(\cdot), \cdot\right)}{\partial B \partial K_{1}}=-(\tau+c) \theta F^{\prime}\left(\hat{e}_{2 i}\right) \frac{\partial \hat{e}_{2 i}}{\partial K_{1}}>0, \\
& \Delta_{22}^{\prime}=\frac{\partial^{2} V_{1}\left(K_{1 f}(\cdot), B_{f}(\cdot), \cdot\right)}{\partial B^{2}}=-(\tau+c) \theta F^{\prime}\left(\hat{e}_{2 i}\right) \frac{\partial \hat{e}_{2 i}}{\partial B}<0 .
\end{aligned}
$$

The positive sign given by (22a) is depicted by the line $Y^{f} Y^{f}$ in Figure 2, which indicates that as the first-best firm installs a larger capacity in period 1, its net marginal benefit of debt

13 This is the second-order condition for $K_{1 f}(\cdot)$ to be an interior solution. We will adopt this requirement. 
financing will be higher; and therefore, the first-best firm will issue more bonds. For both $K_{1 f}(\cdot)$ and $B_{f}(\cdot)$ to satisfy an interior solution, it is also required that:

$$
\Delta_{11}^{\prime} \Delta_{22}^{\prime}-\Delta_{12}^{\prime} \Delta_{21}^{\prime}>0 .
$$

We will assume this holds, which implies that line $Y^{f} Y^{f}$ is steeper than line $X^{f} X^{f}$ in Figure 2. Comparing condition $\left(9^{\prime}\right)$ with condition (19) yields Proposition 3.

Proposition 3: The first-best firm will install a larger capacity in period 1 than the second-best firm, given that both firms choose the same debt level.

The intuition behind Proposition 3 is as follows. Condition (19) includes one more term, $\partial V_{1 D}\left(K_{1 f}(\cdot), B_{f}(\cdot), \cdot\right) / \partial K_{1}$, than condition $\left(9^{\prime}\right)$. From $(12 \mathrm{a})-(12 \mathrm{c})$, this term is positive, indicating that, given that both the first- and second-best firms choose the same debt level, the first-best firm's debtholders will be better off if the firm installs a larger capacity in period 1 . Consequently, the first-best firm would rather install a larger capacity in period 1 as compared to the second-best firm that is unconcerned with its debtholders. This is why $X^{s} X^{s}$ lies below line $X^{f} X^{f}$ in Figure 2. Comparing condition $\left(16^{\prime}\right)$ with condition (20) yields Proposition 4.

Proposition 4: The first-best firm will issue more bonds than the second-best firm, given that both firms install the same capacity in period 1 .

The intuition behind Proposition 4 is as follows. Condition $\left(16^{\prime}\right)$ includes one more term, the first term on the left-hand side of $\left(16^{\prime}\right)$, than condition (20). As mentioned before, this term is negative, thus suggesting that the second-best firm will incur an agency cost associated with the debt overhang problem. The first-best firm is able to avoid such an agency cost, and it will therefore issue more bonds than the second-best firm, given that both firms install the same capacity in period 1. This is why line $Y^{s} Y^{s}$ is to the left of line $Y^{f} Y^{f}$ in Figure 2.

Combining Propositions 3 and 4 yields Proposition 5 that allows investment and financing decisions to interact with each other. 
Proposition 5: As compared to the second-best firm, the first-best firm (i) issues more bonds, (ii) installs a larger capacity in period 1, (iii) may have a higher, a lower, or the same bankruptcy probability in period 2 , and (iv) has higher debt value.

\section{Proof: See Appendix B.}

The intuition behind Proposition 5 is as follows. Both the firstand second-best firms will install the same capacity if both issue no bonds because both will then have the same objective, i.e., to maximize unleveraged equity value. Based on (17a) (or line $X^{s} X^{s}$ in Figure 2), the second-best firm will install a lower capacity in period 1 if it issues bonds than if it does not. Based on (21a) (or line $X^{f} X^{f}$ in Figure 2), the first-best firm will install a larger capacity if it issues bonds than if it does not. Accordingly, the first-best firm will always install period 1 capacity (denoted by $K_{1 f}$ in Figure 2) larger than that of the second-best one (denoted by $K_{1 s}$ in Figure 2) even if we allow interactions between investment and financing decisions. It follows that the first-best firm will choose a debt level (denoted by $B_{f}$ in Figure 2) that is larger than that chosen by the second-best firm (denoted by $B_{s}$ in Figure 2). This is because, based on (22a) and (18a), respectively, the first- and second-best firms will both issue more bonds when installing a larger capacity in period 1 .

However, it is indefinite whether the first-best firm will be less likely to declare bankruptcy than the second-best firm. Proposition 4 states that, given both firms install the same capacity in period 1, the first-best firm will issue more bonds than the second-best firm. By (A4)-(A6), the first-best firm will then be more likely to declare bankruptcy than the second-best firm. This, however, either more than offsets, less than offsets, or exactly offsets the following effect: Proposition 3 states that, given both firms choose the same debt level, the first-best firm will install a larger capacity in period 1 than the second-best firm. By (A1)-(A3), the first-best firm will then be less likely to declare bankruptcy than the second-best firm.

The first-best firm has higher debt value than the second-best firm, suggesting that the first-best firm can borrow more from the debtholders than the second-best firm. This results from the following two effects that reinforce each other. First, based on Proposition 3, given that both firms choose the same debt level, 
the second-best firm will choose a capacity in period 1 lower than that chosen by the first-best firm because the second-best firm is concerned only with its equityholders. By (12a)-(12c), the secondbest firm will have lower debt value than the first-best firm. Second, because of Proposition 4, given that both firms choose the same capacity in period 1 , the second-best firm will issue fewer bonds and will thus have lower debt value than the first-best firm.

The results of Propositions 3-5 can be compared with those of Myers (1977). Those results of Propositions 3 and 4 are implications of Myers' analysis. However, Myers does not endogenize the capital structure decision nor does he consider the sequential investment decision where capital is not readily reversible or is more costly to purchase later. Accordingly, Myers does not yield a result comparable to that stated in Proposition 5.

\section{NUMERICAL ANALYSIS}

We demonstrate the results in the preceding section through numerical examples. We assume that the return to capital in period 1 is given by $r\left(K_{1}\right)=K_{1}^{\alpha}$ and the return to capital in period 2 is given by $R\left(K_{2}, e_{2}\right)=K_{2}^{\alpha} e_{2}$. The term $e_{2}$ is uniformly distributed over the interval $\left[\underline{e}_{2}, \bar{e}_{2}\right]\left(\bar{e}_{2}>\underline{e}_{2}\right)$ with a cumulative distribution $F\left(e_{2}\right)=\left(e_{2}-\underline{e}_{2}\right) /\left(\bar{e}_{2}-\underline{e}_{2}\right)$. The base-case parameter values are chosen as follows: the risk-adjusted discount factor $\theta=0.9$, the purchase price of capital in period $1 b=1$, the purchase price of capital in period $2 b_{h}=1.05,{ }^{14}$ the resale price of capital in period $2 b_{l}=0.2,{ }^{15}$ the bargaining cost per unit shortfall of the net return to capital in period 2 from debt obligations $c=0.2,{ }^{16}$ the output elasticity of capital $\alpha=0.3$, $\underline{e}_{2}=0.25, \bar{e}_{2}=3.75,{ }^{17}$ and the corporate tax rate $\tau=0.2$. The

14 This is a little higher than that in the study by Quigg (1993) which assumes that the development costs of real estate is expected to grow at a rate equal to $3 \%$ per year.

15 This is a little lower than that in the study by Berger et al. (1996) which reports that the mean ratio of exit value of equity to the present value of expected cash flow being equal to 0.344 .

16 There is no comparable data in the literature which presents the data regarding the ratio of the direct bankruptcy costs relative to total firm value. For example, Grinblatt and Titman (2002, p. 560) indicate that this ratio is 2 to $3 \%$ for large US corporations, while it is $20-25 \%$ for small US corporations.

17 We assume that the mean return to capital in period 2 is twice, i.e. the average of $\underline{e}_{2}$ and $\bar{e}_{2}$, as that of the return to capital in period 1 . 
terms $b, b_{h}$, and $\theta$ are chosen to satisfy the convergence requirement $b>\theta b_{h}$. The tax rate $\tau$ reflects personal tax advantages to equity returns that lower the tax advantage of debt to below the corporate rate of $35 \%$ (Leland, 1998).

Given the base-case parameter values, Tables 1 and 2 respectively show the optimal capacity in period 1, the optimal level of bonds, the critical state where bankruptcy just occurs in period 2 , debt and total firm values in period 1, and the debt-to-firm value ratio for both the first- and second-best firms as a function of $b_{h}$ in a region over [1.01, 1.09], $b_{l}$ in a region over [0.1, 0.3], and $c$ in a region over $[0.1,0.3]$, holding all other parameters at their benchmark values. These numerical results are the

\section{Table 1}

Choices of Debt Levels, $B_{f}(\cdot)$, Choices of Period 1 Capacity, $K_{1 f}(\cdot)$, the Critical Level of $e_{2}$ Where Bankruptcy Has Just Occurred, $\hat{e}_{2 m}$, Debt Value, $V_{1 D}\left(K_{1 f}(\cdot), B_{f}(\cdot), \cdot\right)$, Total Firm Value $V_{1}\left(K_{1 f}(\cdot), B_{f}(\cdot), \cdot\right)$, and the Debt-to-Firm Value Ratio $V_{1 D}\left(K_{1 f}(\cdot), B_{f}(\cdot), \cdot\right) / V_{1}\left(K_{1 f}(\cdot), B_{f}(\cdot), \cdot\right)$ for the First-Best Firm

\begin{tabular}{lcccccc}
\hline $\begin{array}{l}\text { Exogenous } \\
\text { Variables }\end{array}$ & $B_{f}(\cdot)$ & $K_{1 f}(\cdot)$ & $\hat{e}_{2 m}$ & $V_{1 D}\left(K_{1 f}(\cdot), B_{f}(\cdot), \cdot\right) V_{1}\left(K_{1 f}(\cdot), B_{f}(\cdot), \cdot\right)$ & $\frac{V_{1 D}\left(K_{1 f}(\cdot), B_{f}(\cdot), \cdot\right)}{V_{1}\left(K_{1 f}(\cdot), B_{f}(\cdot) \cdot\right)}$ \\
\hline$b_{h}$ & & & & & \\
1.010 & 1.915 & 0.866 & 2.000 & 1.2730 & 1.6498 & 0.7716 \\
1.030 & 1.919 & 0.871 & 2.000 & 1.2750 & 1.6494 & 0.7730 \\
1.050 & 1.922 & 0.876 & 2.000 & 1.2774 & 1.6491 & 0.7746 \\
1.070 & 1.925 & 0.880 & 2.000 & 1.2792 & 1.6489 & 0.7758 \\
1.090 & 1.927 & 0.883 & 2.000 & 1.2809 & 1.6487 & 0.7769 \\
$b_{l}$ & & & & & & \\
0.100 & 1.914 & 0.864 & 2.000 & 1.2706 & 1.6474 & 0.7713 \\
0.150 & 1.917 & 0.868 & 2.000 & 1.2726 & 1.6478 & 0.7723 \\
0.200 & 1.922 & 0.876 & 2.000 & 1.2774 & 1.6491 & 0.7746 \\
0.250 & 1.930 & 0.889 & 2.000 & 1.2855 & 1.6515 & 0.7784 \\
0.300 & 1.942 & 0.907 & 2.000 & 1.2975 & 1.6552 & 0.7839 \\
$c$ & & & & & & \\
0.100 & 2.508 & 0.907 & 2.582 & 1.5105 & 1.6997 & 0.8887 \\
0.150 & 2.172 & 0.889 & 2.250 & 1.3848 & 1.6707 & 0.8289 \\
0.200 & 1.922 & 0.876 & 2.000 & 1.2774 & 1.6491 & 0.7746 \\
0.250 & 1.730 & 0.865 & 1.806 & 1.1837 & 1.6324 & 0.7251 \\
0.300 & 1.577 & 0.857 & 1.652 & 1.1080 & 1.6191 & 0.6843 \\
\hline
\end{tabular}

Note:

The parameter values for the benchmark case are $b=1, \theta=0.9, b_{h}=1.05, b_{l}=0.2$, $c=0.2, \alpha=0.3, \underline{e_{2}}=0.25, \overline{e_{2}}=3.75$, and $\tau=0.2$. 


\section{Table 2}

Choices of Debt Levels, $B_{s}(\cdot)$, Choices of Period 1 Capacity, $K_{1 s}(\cdot)$, the Critical Level of $e_{2}$ Where Bankruptcy Has Just Occurred, $\hat{e}_{2 m}$, Debt Value, $V_{1 D}\left(K_{1 s}(\cdot), B_{s}(\cdot), \cdot\right)$, Total Firm Value $V_{1}\left(K_{1 s}(\cdot), B_{s}(\cdot), \cdot\right)$, and the Debt-to-Firm Value Ratio $V_{1 D}\left(K_{1 s}(\cdot), B_{s}(\cdot), \cdot\right) / V_{1}\left(K_{1 s}(\cdot), B_{s}(\cdot), \cdot\right)$ for the Second-Best Firm

\begin{tabular}{lcccccc}
\hline $\begin{array}{l}\text { Exogenous } \\
\text { Variables }\end{array}$ & $B_{s}(\cdot)$ & $K_{1 s}(\cdot)$ & $\hat{e}_{2 m}$ & $V_{1 D}\left(K_{1 s}(\cdot), B_{s}(\cdot), \cdot\right)$ & $V_{1}\left(K_{1 s}(\cdot), B_{s}(\cdot), \cdot\right)$ & $\frac{V_{1 D}\left(K_{1 s}(\cdot), B_{s}(\cdot), \cdot\right)}{V_{1}\left(K_{1 s}(\cdot), B_{s}(\cdot), \cdot\right)}$ \\
\hline$b_{h}$ & & & & & & \\
1.010 & 1.264 & 0.563 & 1.502 & 0.9346 & 1.6120 & 0.5798 \\
1.030 & 1.276 & 0.571 & 1.509 & 0.9418 & 1.6122 & 0.5842 \\
1.050 & 1.287 & 0.579 & 1.517 & 0.9489 & 1.6124 & 0.5885 \\
1.070 & 1.298 & 0.586 & 1.524 & 0.9556 & 1.6128 & 0.5925 \\
1.090 & 1.309 & 0.593 & 1.531 & 0.9621 & 1.6132 & 0.5964 \\
$b_{l}$ & & & & & & \\
0.100 & 1.290 & 0.578 & 1.521 & 0.9496 & 1.6120 & 0.5891 \\
0.150 & 1.289 & 0.578 & 1.520 & 0.9495 & 1.6121 & 0.5890 \\
0.200 & 1.287 & 0.579 & 1.517 & 0.9489 & 1.6124 & 0.5885 \\
0.250 & 1.284 & 0.580 & 1.512 & 0.9481 & 1.6132 & 0.5877 \\
0.300 & 1.278 & 0.582 & 1.504 & 0.9467 & 1.6145 & 0.5864 \\
$c$ & & & & & & \\
0.100 & 1.387 & 0.543 & 1.666 & 1.0125 & 1.6318 & 0.6205 \\
0.150 & 1.340 & 0.562 & 1.593 & 0.9818 & 1.6217 & 0.6054 \\
0.200 & 1.287 & 0.579 & 1.517 & 0.9489 & 1.6124 & 0.5885 \\
0.250 & 1.234 & 0.595 & 1.443 & 0.9158 & 1.6041 & 0.5709 \\
0.300 & 1.185 & 0.609 & 1.375 & 0.8848 & 1.5968 & 0.5541 \\
\hline
\end{tabular}

Note:

Same as Table 1.

outcomes of the joint optimization of debt financing, period 1 capacity, and period 2 bankruptcy decisions, but we will only briefly discuss them. ${ }^{18}$

First let us take a look at the differences between the first- and second-best firms as suggested by Proposition 5. As compared to the second-best firm, the first-best firm not only installs a larger period 1 capacity $\left(K_{1 f}(\cdot)>K_{1 s}(\cdot)\right)$, but is also more likely to declare bankruptcy in period 2. Furthermore, the first-best firm, which is able to avoid the agency cost of debt, will take on more debt than the second-best firm both in the absolute sense (since $B_{f}(\cdot)>B_{s}(\cdot)$ and $\left.V_{1 D}\left(K_{1 f}(\cdot), B_{f}(\cdot), \cdot\right)>V_{1 D}\left(K_{1 s}(\cdot), B_{s}(\cdot), \cdot\right)\right)$

18 Formal proof for these numerical results can be obtained from the authors upon request. 
and in the relative sense (since its debt-to-firm value ratio is higher than that of the second-best firm). We see that these differences are quite significant at the benchmark parameter values. As compared to the second-best firm, the first-best firm issues $49 \%(1.922 / 1.287=1.49)$ more bonds, installs $51 \%$ $(0.876 / 0.579=1.51)$ more capacity in period 1 , is $38 \%$ more likely to fall into bankruptcy in period $2(50 \% / 36.2 \%=1.38)$, has $35 \%$ more debt value $(1.2774 / 0.9489=1.35)$, and has $31.6 \%$ more debt-to-firm value ratio $(0.7746 / 0.5885=1.316)$.

Consider how a change in the purchase and resale prices of capital in period 2 and the bargaining cost affects total firm value in period 1 . Tables 1 and 2 show that irrespective of the strategy a firm takes, the firm that resells capital at a higher price in period 2 or faces a lower bargaining cost will yield higher total firm value in period 1. Tables 1 and 2 also show that total firm value in period 1 for the first-best firm will be lower, while that for the second-best firm will be higher, as the purchase price of capital in period 2 is higher.

Consider the measure of the agency cost of debt. As Myers (1977) indicates, the existence of debt creates situations ex post where a firm's manager can serve its equityholders' interests only by making sub-optimal decisions. Ex ante, this reduces firm value, and therefore, creates an agency cost of debt. This agency cost should be borne by the firm's equityholders. Myers, however, also indicates that this agency cost is difficult to eliminate mainly because the costs to monitor and enforce contracts are too high. Consequently, the first-best firm investigated in this article is an 'ideal' one, which may be uncommon in the real world. Following the standard literature (e.g., Leland, 1998; and Mauer and Ott, 2000), we define the agency cost as the difference between the first- and second-best firm values. Table 3 shows that the agency cost of debt as a percentage of the second-best firm value ranges from $1.4 \%$ to $4.16 \%$, indicating that agency costs of debt are modest. Our finding may be not so surprising as it stands because Leland (1998) finds that the agency cost of debt arising from the 'asset substitution' problem is only $1.37 \%$ of the second-best firm value (see note 3 ).

Consider how a change in the purchase and resale prices of capital in period 2 and the bargain cost affects debt value in period 1 and debt-to-firm value ratio. Tables 1 and 2 show that 
Table 3

The Agency Cost of Debt

\begin{tabular}{lcc}
\hline $\begin{array}{l}\text { Exogenous } \\
\text { Variables }\end{array}$ & Agency Cost $=V_{1}\left(K_{1 f}(\cdot), B_{f}(\cdot), \cdot\right)-V_{1}\left(K_{1 s}(\cdot), B_{s}(\cdot), \cdot\right)$ & $\frac{\text { Agency Cost }}{V_{1}\left(K_{1 s}(\cdot), B_{s}(\cdot) \cdot\right)}(\%)$ \\
\hline$b_{h}$ & & \\
1.010 & 0.0378 & 2.34 \\
1.030 & 0.0372 & 2.31 \\
1.050 & 0.0367 & 2.28 \\
1.070 & 0.0361 & 2.24 \\
1.090 & 0.0355 & 2.20 \\
$b_{l}$ & & \\
0.100 & 0.0354 & 2.20 \\
0.150 & 0.0357 & 2.21 \\
0.200 & 0.0367 & 2.28 \\
0.250 & 0.0383 & 2.37 \\
0.300 & 0.0407 & 2.52 \\
$c$ & & \\
0.100 & 0.0679 & 4.16 \\
0.150 & 0.0490 & 3.02 \\
0.200 & 0.0367 & 2.28 \\
0.250 & 0.0283 & 1.76 \\
0.300 & 0.0223 & 1.40 \\
\hline
\end{tabular}

Note:

Same as Table 1.

irrespective of the strategy a firm takes, the firm that purchases capital at a higher price in period 2 or faces a lower bargaining cost will have higher debt value in period 1 and higher debt-tofirm value ratio. Tables 1 and 2 also show that both debt value in period 1 and debt-to-firm value ratio for the first-best firm will be higher, while that for the second-best firm will be lower, as the resale price of capital in period 2 is higher.

Consider how a change in the purchase and resale prices of capital in period 2 and the bargaining cost affects the choices of debt levels and period 1 capacity. Tables 1 and 2 indicate that irrespective of the strategy a firm takes, the firm that purchases capital at a higher price in period 2 will issue more bonds and also install a larger capacity in period 1 . Suppose that the resale price of capital in period 2 is increased. Table 1 indicates that the first-best firm will then issue more bonds and also install a larger capacity in period 1, while Table 2 indicates that the second-best firm will then issue fewer bonds and also install a 
larger capacity in period 1. Finally, consider a rise in the bargaining cost. Table 1 indicates that the first-best firm will then issue fewer bonds and install a smaller capacity in period 1, while Table 2 indicates that the second-best firm will then issue fewer bonds and install a larger capacity in period 1 .

Consider how a change in the purchase and resale prices of capital in period 2, and the bargaining cost affects the incentive to fall into bankruptcy in that period. Table 1 indicates that a rise in either the purchase or resale price of capital in period 2 is unrelated to the first-best firm's bankruptcy decision in period 2. Table 1 also shows that the first-best firm that faces a higher bargaining cost will be less susceptible to bankruptcy in period 2. Finally, Table 2 indicates that the second-best firm is more susceptible to bankruptcy as the firm purchases capital at a higher price in period 2, sells capital at a lower price in period 2 , or faces a lower bargaining cost.

\section{CONCLUSION}

The seminal paper by Modigliani and Miller (1958) states that a firm's financing decision is distinct from its investment decision under perfect market assumptions. In this article, these two decisions are linked through four sources of market imperfections. First, capital has some resale value and is more costly to purchase later. Second, debt obligations are tax deductible with full loss offsets. Third, conflicts of interest between equity and debt holders over the choice of initial capacity may arise because equity has limited liability. Finally, there are certain costs associated with the event of bankruptcy.

This article compares the investment and financing decisions of a firm that adopts the first-best investment option exercise strategy with those of a firm that adopts the second-best one. The former issues bonds upon deciding an initial capacity, while the latter first issues bonds, and only then decides its initial capacity. In the case of each firm, uncertainty arises after the initial capacity is decided. After the uncertainty is resolved, the equityholders choose a new level of capacity if the state of nature is good enough. If it is not, the firm will go bankrupt and the debtholders will choose a new level of capacity. Debt 
obligations are tax deductible and there are certain costs that are associated with bankruptcy. A firm that adopts the secondbest strategy will both issue fewer bonds and also install a smaller initial capacity than a firm that adopts the first-best one. By using plausible parameter values, this article also finds that firm value difference between these two firms (i.e., the agency cost of debt) is modest.

We may extend this article to investigate the 'asset substituting' problem pointed out by Jensen and Meckling (1976). This can be done by assuming that a firm endogenously chooses the variance of the return to capital in period 2 rather than facing an exogenously given return distribution. As a result, we are able to investigate differences in the investment, financing, and risk choices between the first- and second-best firms. These differences can then be compared with those of Leland (1998) who investigates the issue of asset substitution in a dynamic continuous-time framework.

\section{APPENDIX A}

Totally differentiating equations (6a)-(6c) with respect to $K_{1}, B$, $b_{h}$, and $b_{l}$ yields the following comparative static results:

$$
\begin{gathered}
\frac{\partial \hat{e}_{2 m}}{\partial K_{1}}=\frac{-R_{K_{2}}\left(K_{1}, \hat{e}_{2 m}\right)}{R_{e_{2}}\left(K_{1}, \hat{e}_{2 m}\right)}<0, \\
\frac{\partial \hat{e}_{2 h}}{\partial K_{1}}=\frac{-b_{h}}{R_{e_{2}}\left(K_{2}\left(\hat{e}_{2 h}\right), \hat{e}_{2 h}\right)}<0, \\
\frac{\partial \hat{e}_{2 l}}{\partial K_{1}}=\frac{-b_{l}}{R_{e_{2}}\left(K_{2}\left(\hat{e}_{2 l}\right), \hat{e}_{2 l}\right)}<0, \\
\frac{\partial \hat{e}_{2 m}}{\partial B}=\frac{1}{R_{e_{2}}\left(K_{1}, \hat{e}_{2 m}\right)}>0, \\
\frac{\partial \hat{e}_{2 h}}{\partial B}=\frac{1}{R_{e_{2}}\left(K_{2}\left(\hat{e}_{2 h}\right), \hat{e}_{2 h}\right)}>0,
\end{gathered}
$$




$$
\begin{gathered}
\frac{\partial \hat{e}_{2 l}}{\partial B}=\frac{1}{R_{e_{2}}\left(K_{2}\left(\hat{e}_{2 l}\right), \hat{e}_{2 l}\right)}>0, \\
\frac{\partial \hat{e}_{2 h}}{\partial b_{h}}=\frac{K_{2}\left(\hat{e}_{2 h}\right)-K_{1}}{R_{e_{2}}\left(K_{2}\left(\hat{e}_{2 h}\right), \hat{e}_{2 h}\right)}>0, \\
\frac{\partial \hat{e}_{2 l}}{\partial b_{l}}=\frac{K_{2}\left(\hat{e}_{2 l}\right)-K_{1}}{R_{e_{2}}\left(K_{2}\left(\hat{e}_{2 l}\right), \hat{e}_{2 l}\right)}<0 .
\end{gathered}
$$

This completes the proof.

\section{APPENDIX B}

Evaluating the left-hand side of both (19) and (20) at $K_{1}=K_{1 s}(\cdot)$, and $B=B_{s}(\cdot)$, linearizing them around $K_{1 f}(\cdot)$ and $B_{f}(\cdot)$, and using both (19) and (20) yields:

$$
\left[\begin{array}{c}
\frac{\partial V_{1}\left(K_{1 s}(\cdot), B_{s}(\cdot), \cdot\right)}{\partial K_{1}} \\
\frac{\partial V_{1}\left(K_{1 s}(\cdot), B_{s}(\cdot) \cdot\right)}{\partial B}
\end{array}\right]=\left[\begin{array}{cc}
\Delta_{11}^{\prime} & \Delta_{21}^{\prime} \\
\Delta_{12}^{\prime} & \Delta_{22}^{\prime}
\end{array}\right]\left[\begin{array}{c}
K_{1 s}(\cdot)-K_{1 f}(\cdot) \\
B_{s}(\cdot)-B_{f}(\cdot)
\end{array}\right],
$$

where:

$\Delta_{11}^{\prime}, \Delta_{12}^{\prime}, \Delta_{21}^{\prime}$ and $\Delta_{22}^{\prime}$ are given by (21b), (21c), (22b) and (22c), respectively. Solving (B 1) yields:

$$
\left[\begin{array}{c}
K_{1 s}(\cdot)-K_{1 f}(\cdot) \\
B_{s}(\cdot)-B_{f}(\cdot)
\end{array}\right]=\left[\begin{array}{ll}
\nabla_{11} & \nabla_{21} \\
\nabla_{12} & \nabla_{22}
\end{array}\right]\left[\begin{array}{c}
\frac{\partial V_{1}\left(K_{1 s}(\cdot), B_{s}(\cdot), \cdot\right)}{\partial K_{1}} \\
\frac{\partial V_{1}\left(K_{1 s}(\cdot), B_{s}(\cdot), \cdot\right)}{\partial B}
\end{array}\right],
$$

where:

$$
\begin{aligned}
& \nabla_{11}=\Delta_{22}^{\prime} /\left(\Delta_{11}^{\prime} \Delta_{22}^{\prime}-\Delta_{12}^{\prime} \Delta_{21}^{\prime}\right)<0, \\
& \nabla_{12}=-\Delta_{21}^{\prime} /\left(\Delta_{11}^{\prime} \Delta_{22}^{\prime}-\Delta_{12}^{\prime} \Delta_{21}^{\prime}\right)<0, \\
& \nabla_{21}=-\Delta_{12}^{\prime} /\left(\Delta_{11}^{\prime} \Delta_{22}^{\prime}-\Delta_{12}^{\prime} \Delta_{21}^{\prime}\right)<0, \\
& \nabla_{22}=\Delta_{11}^{\prime} /\left(\Delta_{11}^{\prime} \Delta_{22}^{\prime}-\Delta_{12}^{\prime} \Delta_{21}^{\prime}\right)<0 .
\end{aligned}
$$

Given that $\frac{\partial V_{1}\left(K_{1 s}(\cdot), B_{s}(\cdot), \cdot\right)}{\partial K_{1}}=\frac{\partial V_{1 D}\left(K_{1 s}(\cdot), B_{s}(\cdot), \cdot\right)}{\partial K_{1}}>0$ (by (12a)-(12c)) and $\frac{\partial V_{1}\left(K_{1 s}(\cdot), B_{s}(\cdot), \cdot\right)}{\partial B}>0 \quad$ (by $\left.(16)\right)$, from (B2), we thus derive $K_{1 f}(\cdot)>K_{1 s}(\cdot)$ and $B_{f}(\cdot)>B_{s}(\cdot)$.

This completes the proof. 


\section{REFERENCES}

Abel, A.B., A.K. Dixit, J.C. Eberly and R.S. Pindyck (1996), 'Options, the Value of Capital, and Investment,' Quarterly Journal of Economics, Vol. 111, pp. 753-77.

Altman, E.I. (1984), 'An Empirical Investigation of the Bankruptcy Cost Question,' Journal of Finance, Vol. 39, pp. 1067-89.

Berger, P.G., E. Ofek and I. Swary (1996), 'Investor Valuation of the Abandonment Option,' Journal of Finance Economics, Vol. 24, pp. 257-87.

Brander, J.A. and T.R. Lewis (1986), 'Oligopoly and Financial Structure: The Limited Liability Effect,' American Economic Review, Vol. 76, pp. 956-70.

Canadian Journal of Economics, Vol. 21, pp. 221-43.

and B.J. Spencer (1989), 'Moral Hazard and Limited Liability: Implications for the Theory of the Firm,' International Economic Review, Vol. 30, pp. 833-49.

Callen, J.L. and D.S. Gelb (2000), 'Corporate Leverage and Unanticipated Industry Growth: A Test of the Myers Conjecture' (mimeo).

Dasgupta, S. and K. Sengupta (1993), 'Sunk Investment, Bargaining and Choice of Capital Structure,' International Economic Review, Vol. 34, pp. 203-20.

Fries, S., M. Miller and W. Perraudin (1997), 'Debt in Industry Equilibrium,' Review of Financial Studies, Vol. 10, pp. 39-67.

Grinblatt, M. and S. Titman (2002), Financial Markets and Corporate Strategy (2nd ed., McGraw-Hill).

Harris, M. and A. Raviv (1991), 'The Theory of Capital Structure,' Journal of Finance, Vol. 46, pp. 297-355.

Haugen R. and L.W. Senbet (1978), 'The Insignificance of Bankruptcy Costs to the Theory of Optimal Capital Structure,' Journal of Finance, Vol. 33, pp. 383-93.

Jensen, M.C. and W.H. Meckling (1976), 'Theory of the Firm: Managerial Behavior, Agency Costs, and Capital Structure,' Journal of Financial Economics, Vol. 4, pp. 177-203.

Jou, J.B. (2001a), 'Entry, Financing, and Bankruptcy Decisions: The Limited Liability Effect,' Quarterly Review of Economics and Finance, Vol. 41, pp. 69-88.

L $(2001 \mathrm{~b})$, 'Corporate Borrowing and Growth Option Value: The Limited Liability Effect,' Journal of Economics and Finance, Vol. 25, pp. 80-99.

(2001c), 'Capacity Expansion, Bankruptcy, and Financing Decisions' (mimeo).

Lambrecht, B.M. (2001), 'The Impact of Debt Financing on Entry and Exit in a Duopoly,' Review of Financial Studies, Vol. 14, pp. 765-804.

Leland, H.E. (1994), 'Corporate Debt Value, Bond Covenants, and Optimal Capital Structure,' Journal of Finance, Vol. 49, pp. 1213-52.

- (1998), 'Agency Costs, Risk Management, and Capital Structure,' Journal of Finance, Vol.53, pp. 1213-44.

Mauer, D.C. and S.H. Ott (2000), 'Agency Costs, Investment Policy and Optimal Capital Structure: The Effect of Growth Options,' in M.J. Brennan and L. Trigeorgis (eds.), Project Flexibility, Agency, and Product Market Competition: New Developments in the Theory and Application of Real Options (London: Oxford University Press) pp. 151-79. 
Mauer, D.C. and A.J. Triantis (1994), 'Interactions of Corporate Financing and Investment Decisions: A Dynamic Framework,' Journal of Finance, Vol. 49, pp. 1253-77.

Mella-Barral, P. and W. Perraudin (1997), 'Strategic Debt Service,' Journal of Finance, Vol. 52, pp. 531-56.

Mello, A.S. and J.E. Parsons (1992), 'The Agency Costs of Debt,' Journal of Finance, Vol. 47, pp. 1887-904.

and A.J. Triantis (1995), 'An Integrated Model of Multinational Flexibility and Financial Hedging,' Journal of International Economics, Vol. 39, pp. 27-51.

Modigliani, F. and M.H. Miller (1958), 'The Cost of Capital, Corporate Finance, and the Theory of Investment,' American Economic Review, Vol. 48, pp. 261-97.

Myers, S.C. (1977), 'Determinants of Corporate Borrowing,' Journal of Financial Economics, Vol. 5, pp. 147-76.

Quigg, L. (1993), 'Empirical Testing of Real Option-Pricing Models, “Journal of Finance, Vol. 48, pp. 621-40

Tobin, J. (1969), 'A General Equilibrium Approach to Monetary Theory,' Journal of Money, Credit and Banking, Vol. 1, pp. 15-29.

Warner, J.B. (1977), 'Bankruptcy Costs: Some Evidence,' Journal of Finance, Vol. 32, pp. 337-48. 